\title{
Arkadiusz Durasiewicz
}

Wyższa Szkoła Pedagogiczna im. Janusza Korczaka w Warszawie

e-mail: a.durasiewicz@wspkorczak.eu

\section{ANALIZA PROGRAMÓW POLITYKI RODZINNEJ W LATACH 1997-2013}

\section{ANALYSIS OF FAMILY POLICY PROGRAMS IN THE YEARS 1997-2013}

DOI: $10.15611 / \mathrm{pn} .2016 .456 .01$

JEL Classification: H75, I31, I32, I38

\begin{abstract}
Streszczenie: Artykuł ma na celu przedstawienie i analizę programów polityki rodzinnej w Polsce w latach 1997-2013. W tekście zaprezentowano analizę danych źródłowych, wykorzystując następujące metody badawcze: metodę deskrypcji, metodę gromadzenia wiadomości oraz analizy zebranego materiału. W pracy posłużono się również metodą porównawczą. Porównywano różne podejścia dotyczące założeń w poszczególnych programach polityki rodzinnej. Źródłami wykorzystanymi w tej metodzie były literatura przedmiotu, strony internetowe oraz różnego rodzaju dokumenty i materiały źródłowe. Zastosowana analiza pozwoliła na zbadanie i przedstawienie rozwoju programów polityki rodzinnej, w ciągu prawie 20 lat od momentu pierwszej projekcji.
\end{abstract}

Słowa kluczowe: polityka rodzinna, programy, rodzina, analiza

\begin{abstract}
Summary: The article presents and analyzes the programs of Polish family policy in the years 1997-2013. The article used the analysis of the source data by using the following test methods: a method of descriptions, the method of gathering information and thea nalysis of the collected material. The study also used a research method applied among other science of politics as a comparative method. Using this method different approaches regarding the assumptions in various programs of family policy were compared. The sources used were literature of the subject, websites and various documents and source materials. The applied analysis enabled the identification and presentation of the development programs of family policy, during nearly 20 years since the first projection.
\end{abstract}

Keywords: family policy, programs, family, analysis.

\section{Wstęp}

Zainteresowanie państwa rozwijaniem polityki na rzecz rodzin było spowodowane wieloma czynnikami - w latach 90. w szczególności jako inwestycja w młode poko- 
lenie, przez co polityka rodzina miała stać się pierwszorzędnym elementem działań na rzecz rozwoju społeczeństwa, natomiast od 2007 r. głównie pogłębiającym się niżem demograficznym w Polsce. Obecnie oprócz demograficznych uwarunkowań zainteresowanie państwa polityką na rzecz rodzin wynika z coraz powszechniejszej debaty na temat polityki rodzinnej w Polsce oraz kierunku rozwoju i wyzwań, jakie stoją przed realizacją niniejszej polityki na kolejne lata.

Artykuł ma na celu przedstawienie i analizę programów polityki rodzinnej w Polsce w latach 1997-2013. Ze względu na fakt, że już od pierwszego programu zmieniała się rola i zadania polityki na rzecz rodzin, zauważalne było również zróżnicowane podejście do kwestii polityki rodzinnej implicite i explicite. W artykule wykorzystano analizę danych źródłowych przy jednoczesnym zastosowaniu następujących metod badawczych: metody deskrypcji, metody gromadzenia wiadomości oraz analizy zebranego materiału [Znaniecki 1984, s. 25]. W pracy posłużono się metodą badawczą stosowaną między innymi w naukach o polityce w postaci metody porównawczej [Chodubski 2004, s. 119-126]. Za pomocą tej metody dokonano porównania różnych podejść dotyczących założeń w poszczególnych programach polityki rodzinnej. Zestawiono i skonfrontowano definicje polityki rodzinnej oraz strukturę poszczególnych dokumentów stanowiących podstawy programowe przedstawianych danych źródłowych (struktura dokumentów, ich treść i założone efekty). Źródłami wykorzystanymi w tej metodzie były literatura przedmiotu, strony internetowe (Przymierza Rodzin i Prezydenta RP) oraz różnego rodzaju dokumenty i materiały źródłowe, w szczególności czasopismo „Przegląd Rządowy”, w którym opublikowane zostały projekty programów polityki rodzinnej z 1997 i 1999 r. Zastosowana analiza pozwoliła na przedstawienie rozwoju programów polityki rodzinnej w ciągu prawie 20 lat od momentu pierwszego takiego założenia.

\section{Materiał źródłowy}

Jak już wspomniano we wstępie, materiał źródłowy poszczególnych programów został zaczerpnięty z różnych źródeł literaturowych i internetowych (tab.1). Niezwykle ważny jest jednak sam fakt źródłowy ideologii powstawania poszczególnych programów. Program Polityki Rodzinnej z 1997 r. zakładał, że wspieranie rodziny jest traktowane jako inwestycja w młode pokolenie, przez co polityka rodzina miała stać się głównym elementem działań na rzecz rozwoju społeczeństwa. Odpowiedzialność za warunki życia i los swoich członków spoczywała na rodzinie. Obowiązkiem państwa natomiast było tworzenie warunków umożliwiających rodzinie realizację jej zadań, praw i obowiązków wobec społeczeństwa, a także własny wybór modelu rodziny - jej liczebności i reguł życia wewnątrzrodzinnego. Nie mogły być przy tym naruszone podmiotowość i suwerenność rodziny. Państwo nie jest bowiem monopolistą w polityce rodzinnej; dlatego też w realizację jej celów powinny być włączone samorządy, organizacje lokalne, wspólnoty reprezentujące interesy rodzin, jak i same rodziny. Zwrócono więc uwagę na potrzebę tworzenia przez państwo i inne 
podmioty społeczne warunków umożliwiających rodzinie samodzielne budowanie podstaw egzystencji.

Tabela 1. Materiał źródłowy poszczególnych programów polityki rodzinnej

\begin{tabular}{|c|c|}
\hline Nazwa programu & Źródło \\
\hline $\begin{array}{l}\text { Projekt programu polityki rodzinnej z dnia } \\
10 \text { czerwca } 1997 \text { r. - przygotował } \\
\text { Międzyresortowy Zespół ds. Opracowania } \\
\text { Rządowego Programu Polityki Prorodzinnej }\end{array}$ & „Przegląd Rządowy” nr 8-9 z 1997 r., s. 227-230 \\
\hline $\begin{array}{l}\text { Projekt programu polityki prorodzinnej } \\
\text { z dnia } 3 \text { listopada } 1999 \text { r. - przygotował } \\
\text { Międzyresortowy Zespół ds. Opracowania } \\
\text { Rządowego Programu Polityki Prorodzinnej }\end{array}$ & $\begin{array}{l}\text { „Przegląd Rządowy” nr 11-12 z } 1999 \text { r., } \\
\text { s. 130-143 }\end{array}$ \\
\hline $\begin{array}{l}\text { Projekt polityki rodzinnej z } 8 \text { marca } 2007 \text { r. - } \\
\text { przygotował zespół powołany do stworzenia } \\
\text { projekcji dokumentu pod kierownictwem Joanny } \\
\text { Kluzik-Rostkowskiej }\end{array}$ & $\begin{array}{l}\text { http://www.przymierze.org. } \\
\text { pl/index.php?option=com_- } \\
\text { content\&task=view\&id=141\&Itemid=34 } \\
\text { (dostęp: 8.06.2016) }\end{array}$ \\
\hline $\begin{array}{l}\text { Projekt programu polityki rodzinnej kancelarii } \\
\text { Prezydenta RP z maja } 2013 \text { r. }\end{array}$ & $\begin{array}{l}\text { http://www.prezydent.pl/archiwum-bronislawa- } \\
\text { komorowskiego/dla-rodziny/program-polityki- } \\
\text { rodzinnej-prezydenta-rp/ (dostęp: 8.06.2016) }\end{array}$ \\
\hline
\end{tabular}

Źródło: opracowanie własne na podstawie zebranych materiałów.

W 1997 r. przyjęta została nowa Konstytucja RP, w której określono odpowiedzialność państwa za warunki życia rodzin. W roku tym ówczesny rząd koalicji SLD-PSL przyjął program polityki rodzinnej. W wyniku nowych wyborów parlamentarnych, przeprowadzonych w październiku tegoż roku, do władzy doszły ugrupowania prawicowe (AWS) i centroprawicowe (UW). Zaowocowało to podjęciem prac nad nowym dokumentem „Polityka prorodzinna państwa” [Balcerzak-Paradowska 2004b, s. 255]. Polityka prorodzinna miała stać się istotnym elementem nowego modelu ogólnej polityki społeczno-gospodarczej państwa. Kierunki projektowanych działań objęły różne obszary. Szczególną rolę nadano oddziaływaniu na procesy demograficzne, a przede wszystkim zahamowaniu spadku liczby małżeństw i urodzeń poprzez politykę zatrudnienia i mieszkaniową.

W związku z powyższym przed kolejnymi rządami w latach 1999-2004 stanęła konieczność rozwiązania wciąż narastających problemów społecznych spowodowanych zmianą systemową. Znaczenie rodziny, zarówno w skali mikro, jak i makro, dla funkcjonowania całego społeczeństwa było faktem bezspornym. Dlatego wybór metod i środków eliminowania lub ograniczenia zjawisk dla niej niekorzystnych i wsparcia uzależniono od opcji doktrynalnych reprezentowanych przez poszczególne partie rządzące.

Pierwsze poważne założenia programowe dotyczące przeciwdziałania niekorzystnej tendencji demograficznej w Polsce poczyniono w 2007 r. w opracowanym 
przez ówczesną Minister Pracy i Polityki Społecznej JoannęKluzik-Rostkowską dokumencie (Program Polityki Rodzinnej), w którym stwierdzono, że trzeba wzmocnić i postawić na rodziny wielodzietne i wiejskie. Wielodzietne, bo najczęściej tylko jeden z rodziców pracuje, więc dysponują znacznie skromniejszymi środkami na utrzymanie. Wiejskie, bo oprócz tego, że spora część nich to także rodziny wielodzietne, często nie posiadają dostępu do opieki medycznej i edukacji na wysokim poziomie. Takie podejście powodowało jednak pewną selektywność w podejściu do polityki państwa na rzecz rodzin.

Kolejnym ,przełomowym” programem dotyczącym polityki społecznej na rzecz rodzin, mającym w swoich założeniach zniwelować niekorzystną sytuację demograficzną w Polsce, był program polityki rodzinnej za rządów prezydenta Bronisława Komorowskiego - „Dobry klimat dla rodziny”, opublikowany w maju 2013 r. W ramach zmian, które miały stworzyć dobrą sytuację dla rodzicielstwa, przedstawiono 44 rekomendacje. Program przede wszystkim przewidywał i wprowadził z sukcesem Ogólnopolską Kartę Dużych Rodzin, ustanawiającą powszechne zniżki w opłatach za usługi publiczne dla rodzin wielodzietnych.

\section{Różne próby definiowania polityki rodzinnej w poszczególnych programach}

Przegląd poszczególnych dokumentów wskazuje na różne podejście w zakresie definicji polityki rodzinnej, co pokazuje jak ewaluowała próba kompleksowego ujęcia tego terminu. Według poszczególnych okresów uzależniona była od różnych uwarunkowań dotyczących zarówno kwestii społecznych, ekonomicznych, gospodarczych, jak i politycznych panujących w danym okresie. W 1997 r. do ważnych uwarunkowań należały między innymi procesy demograficzne i transformacje modelu rodziny, rzutujące w znacznym stopniu na przemiany w samych potrzebach, a przez to także na dobór metod i konkretnych rozwiązań polityki społecznej. Procesy te w ogólnym zarysie charakteryzowało wiele wzajemnie powiązanych czynników: wzrost liczby urodzeń związany $\mathrm{z}$ wchodzeniem w wiek wzmożonej aktywności życiowej roczników powojennego wyżu demograficznego, zmiany w podziale ludności według źródeł utrzymania na korzyść zajęć pozarolniczych i wreszcie zmiany w strukturze gospodarstw domowych. Nie mogły być przy tym naruszone podmiotowość i suwerenność rodziny. Państwo nie jest bowiem monopolistą w polityce rodzinnej; dlatego też w realizację jej celów powinny być włączone samorządy, organizacje lokalne, wspólnoty reprezentujące interesy rodzin oraz same rodziny. Zwrócono więc uwagę na potrzebę tworzenia przez państwo i inne podmioty społeczne warunków umożliwiających rodzinie samodzielne budowanie podstaw egzystencji [Balcerzak-Paradowska 2004a, s. 222]. W 1999 r. polityka prorodzinna miała stać się istotnym elementem nowego modelu ogólnej polityki społeczno-gospodarczej państwa. Kierunki projektowanych działań objęły różne obszary. Szczególną rolę nadano oddziaływaniu na procesy demograficzne, a przede wszystkim zaha- 
mowaniu spadku liczby małżeństw i urodzeń poprzez politykę zatrudnienia i mieszkaniową. Poprawie kondycji finansowej rodziny służyć miało tworzenie warunków do aktywności ekonomicznej jej członków zarówno w systemie zatrudnienia, jak i w wyniku rozwoju rodzinnej przedsiębiorczości. Ponadto program zawierał kierunki działań mających pomóc rodzinom z dzieckiem niepełnosprawnym, zagrożonym dysfunkcjami, zapewnić ochronę prawną rodzin, uczestnictwo rodzin w kulturze. W obydwu programach, w tym z 1997 r., i z 1999 r., zbliżone były zapisy odnoszące się do celu polityki rodzinnej. Analogiczne szczegółowe kierunki dotyczyły działań na rzecz własnej aktywności ekonomicznej rodziny, poprawy warunków mieszkaniowych, poprawy dostępu do edukacji i zajęć kulturalno-rekreacyjnych, opieki nad dzieckiem i ochrony zdrowia [Balcerzak-Paradowska 2004a, s. 223].

Rządowe programy polityki rodzinnej odzwierciedlały ideologiczne „korzenie” partii politycznych będących u władzy, które przełożyły się na wartości stanowiące fundament obu programów. Program z 1997 r. przyjęty przez ugrupowania lewicowe akcentował potrzebę pomocy dla rodzin mniej zamożnych i ubogich. W zawartych w nim propozycjach szczegółowych odzwierciedla się akceptacja modelu rodziny z pracującą matką, opartego na partnerstwie. Program zachowywał neutralność w sprawie realizacji prokreacyjnej funkcji rodziny.

Aktywne oddziaływanie na postawy prokreacyjne stanowiło ważny nurt proponowanych działań w ramach programu rządu prawicowego. Celowi temu podporządkowano między innymi rozwiązanie mające na celu wspieranie kobiety w godzeniu obowiązków zawodowych z rodzinnymi [Balcerzak-Paradowska 2004a, s. 224].

W 2007 r. realizacja programu polityki rodzinnej miała przyczynić się do wzrostu liczby narodzin (odwrócenia niekorzystnego trendu demograficznego) oraz poprawy jakości życia i kondycji polskich rodzin. Należało przy tym odróżnić politykę rodzinną od szeroko pojętej polityki społecznej czy społeczno-gospodarczej. Działania miały koncentrować się na wskazaniu takich narzędzi, które ułatwią rodzicom - a w szczególności kobietom - godzenie obowiązków zawodowych z życiem prywatnym. Podobnie, nie wchodziło w zakres opracowania wskazywanie sposobów na zwiększenie dostępności mieszkań, choć sytuacja mieszkaniowa miała oczywisty wpływ na świadome decyzje rodziców o posiadaniu dziecka [Projekt polityki rodzinnej 2007, s. 3-4]. Wiele proponowanych przez projekt polityki rodzinnej rozwiązań zakładało polepszenie ogólnego klimatu dla rodzicielstwa oraz wyeliminowanie, niektórych przynajmniej, uciążliwości życiowych związanych z posiadaniem dziecka. Szczególna uwaga została poświęcona również identyfikacji istniejących rozwiązań prawnych, które pośrednio doprowadzały w ubiegłych latach do rozpadu rodzin.

W 2013 r. pogłębiający się kryzys demograficzny w Polsce spowodował, że działania przedstawione $\mathrm{w}$ programie polityki rodzinnej „Dobry klimat dla rodziny” zakładały rozwiązania na rzecz „odnowy demograficznej”. Miały temu służyć warunki sprzyjające podejmowaniu decyzji o urodzeniu i wychowaniu dzieci, usuwanie barier przeszkadzających w realizacji aspiracji rodzicielskich, takich jak trud- 
Tabela 2. Różne próby definiowania polityki rodzinnej

\begin{tabular}{|c|c|}
\hline Nazwa programu & Definicja \\
\hline $\begin{array}{l}\text { Projekt programu polityki rodzinnej } \\
\text { z dnia } 10 \text { czerwca } 1997 \text { r. - przygotował } \\
\text { Międzyresortowy Zespół ds. Opracowania } \\
\text { Rządowego Programu Polityki Prorodzinnej }\end{array}$ & $\begin{array}{l}\text { Polityka rodzinna to zespół norm prawnych, } \\
\text { działań i środków uruchamianych przez państwo } \\
\text { oraz inne podmioty publiczne i pozarządowe, } \\
\text { mających na celu tworzenie ogólnych, możliwie } \\
\text { najlepszych warunków do zakładania rodzin, ich } \\
\text { rozwoju i dobrego funkcjonowania. }\end{array}$ \\
\hline $\begin{array}{l}\text { Projekt programu polityki prorodzinnej } \\
\text { z dnia } 3 \text { listopada } 1999 \text { r. - przygotował } \\
\text { Międzyresortowy Zespół ds. Opracowania } \\
\text { Rządowego Programu Polityki Prorodzinnej }\end{array}$ & $\begin{array}{l}\text { Polityka prorodzinna to polityka, która } \\
\text { powinna zapewnić trwanie i rozwój rodziny } \\
\text { oraz poszanowanie należnych jej praw, w tym } \\
\text { prawa do samodzielności ekonomicznej oraz } \\
\text { decydowania o wychowaniu dzieci. }\end{array}$ \\
\hline $\begin{array}{l}\text { Projekt polityki rodzinnej z } 8 \text { marca } 2007 \text { r. - } \\
\text { przygotował zespół powołany do stworzenia } \\
\text { projekcji dokumentu pod kierownictwem Joanny } \\
\text { Kluzik-Rostkowskiej }\end{array}$ & $\begin{array}{l}\text { (Polityka rodzinna) rozumiana szeroko jest po } \\
\text { prostu mądrze i sprawnie prowadzoną polityką } \\
\text { państwa, które dba o zdrową gospodarkę, } \\
\text { rozsądnie dzieli publiczne pieniądze, by trafiały } \\
\text { tam, gdzie są najbardziej potrzebne, przykłada } \\
\text { należytą wagę do zdrowia i edukacji obywateli. }\end{array}$ \\
\hline $\begin{array}{l}\text { Projekt programu polityki rodzinnej kancelarii } \\
\text { Prezydenta RP z maja } 2013 \text { r. }\end{array}$ & $\begin{array}{l}\text { Polityka rodzinna nie może narzucać rodzicom } \\
\text { jednego słusznego modelu postępowania, lecz } \\
\text { ma elastycznie odpowiadać na ich potrzeby } \\
\text { i wybory, pozwalać rodzicom wybierać różne } \\
\text { strategie łączenia wychowywania najmłodszych } \\
\text { dzieci z pracą, kształtować zgodnie z ich } \\
\text { preferencjami podział obowiązków w rodzinie } \\
\text { oraz dobierać odpowiednie formy opieki nad } \\
\text { dziećmi. }\end{array}$ \\
\hline
\end{tabular}

Źródło: opracowanie własne na podstawie zebranych materiałów.

ności w godzeniu obowiązków rodzinnych i zawodowych, problemy mieszkaniowe czy wysokie koszty wychowania dzieci. W ramach realizacji tego przedsięwzięcia przedstawione zostały 44 szczegółowe rekomendacje.

\section{Struktura dokumentów, ich treść i założone efekty}

\section{Program polityki rodzinnej z 1997 r.}

„Program polityki rodzinnej” - przyjęty przez Radę Ministrów 10 czerwca 1997 r. - przygotował Międzyresortowy Zespół ds. Opracowania Rządowego „Programu Polityki Prorodzinnej” oraz eksperci reprezentujący środowiska naukowe i praktycy poszczególnych dziedzin życia społecznego. W pracy nad przygotowaniem programu wykorzystano opracowany w 1995 r. przez pełnomocnika rządu ds. rodziny i ko- 
biet „Raport o sytuacji polskich rodzin”, a także wyniki późniejszych analiz dotyczących sytuacji polskich rodzin. Uwzględniono także wnioski z debaty sejmowej przeprowadzonej nad tym raportem w 1996 r. oraz programy szczegółowe: „Krajowy program działań na rzecz kobiet” i „Narodowy program zdrowia”. Program polityki rodzinnej miał być realizowany do 2005 r. „Program Polityki Rodzinnej” był pierwszą po 1989 r. próbą wyznaczenia celów oraz nakreślenia strategii państwa w polityce rodzinnej. W programie postrzegano opiekę instytucjonalną nad dziećmi jako „dopełniającą opiekę rodzinną”, podkreślano również podmiotowość i suwerenność rodziny. $\mathrm{W}$ zakresie proponowanych instrumentów polityki program nie stanowił jednak przełomu: wciąż za najważniejszy instrument bezpośredni uważane były świadczenia pieniężne, rozważano również możliwość ich rozszerzenia przez wprowadzenie ulg podatkowych dla rodzin wychowujących dzieci. Program ostatecznie nie został poddany dyskusji parlamentarnej z powodu upływającej kadencji. Realizacja programu zakładała osiągnięcie następujących efektów [Program Polityki Rodzinnej 1997]:

- polepszenie materialnych podstaw bytu rodziny, wzrostu znaczenia dochodów i pracy oraz poprawę sytuacji mieszkaniowej,

- poprawę sytuacji rodzin mających trudności, poprzez udzielanie im pomocy i uwzględnianie ich aktywności w wychodzeniu ze stanów trudnych,

- zwiększenie aktywności organizacji pozarządowych, jako podmiotów polityki społecznej na rzecz rodzin,

- kształtowanie prorodzinnych postaw społecznych,

- wyrównywanie szans życiowych dzieci z różnych środowisk (dotyczy to potrzeb w zakresie materialnym oraz opieki zdrowotnej, edukacji, kultury, sportu i rekreacji).

\section{Program polityki prorodzinnej z 1999 r.}

„Program polityki prorodzinnej państwa” został przygotowany przez Międzyresortowy Zespół do spraw Opracowania Polityki Prorodzinnej Państwa, powołany przez prezesa Rady Ministrów, a kierowany przez pełnomocnika rządu ds. rodziny. Dokument powstał na podstawie wniosków wynikających z „Raportu o sytuacji polskich rodzin” przyjętego przez Radę Ministrów 21 lipca 1998 r. Jego treść nawiązuje do dokumentu „Program polityki rodzinnej" z $1997 \mathrm{r}$. W porównaniu ze strategią przyjętą w $1997 \mathrm{r}$. przez rząd SLD-PSL znacznie mocniej zaakcentowano w nim kulturowe aspekty funkcjonowania rodzin - jednym z celów „Programu polityki prorodzinnej” było „przygotowanie dzieci i młodzieży do pełnienia funkcji rodzinnych i społecznych” oraz ,zahamowanie spadku liczby zawieranych małżeństw". Dokument rządu AWS-UW mniejszą wagę przykładał do kwestii przeciwdziałania ubóstwu i wykluczeniu społecznemu dzieci, mocno zaś zaakcentował konieczność „inwestycji w kapitał ludzki” - działania z zakresu polityki rodzinnej zostały włączone w strategię rozwoju ekonomicznego kraju. 
Realizacja programu zakładała osiągnięcie następujących efektów [Program polityki prorodzinnej 1999]:

- pomoc rodzinom w uzyskaniu samodzielności finansowej,

- poprawę warunków mieszkaniowych ludności,

- zwiększenie aktywności organizacji pozarządowych, jako podmiotów polityki społecznej,

- przygotowanie dzieci i młodzieży do pełnienia funkcji rodzinnych i społecznych,

- zahamowanie istniejących negatywnych tendencji w rozwoju ludnościowym kraju i poprawę sytuacji demograficznej.

\section{Program polityki rodzinnej z 2007 r.}

Głównym dokumentem programowym koalicji, który miał stać się podstawą nowego, kompleksowego aktu prawnego (ustawy rodzinnej), był „Projekt polityki rodzinnej”, ogłoszony w marcu 2007 r., kiedy premierem koalicyjnego rządu Prawo i Sprawiedliwość - Samoobrona - Liga Polskich Rodzin był Jarosław Kaczyński. Projekt powstawał pod kierunkiem ówczesnej wiceminister w Ministerstwie Pracy i Polityki Społecznej Joanny Kluzik-Rostkowskiej. Podobnie jak to miało miejsce w poprzednim dokumencie, a więc „Programie polityki prorodzinnej” z 1999 r., punktem wyjścia była diagnoza dotycząca dramatycznych perspektyw demograficznych w Polsce - raport przewidywał obniżenie się współczynnika dzietności z 1,22 w 2005 r. do nawet 1,1 w okresie 2010-2020 [Durasiewicz 2016, s. 285]. W reakcji na nadchodzący kryzys autorzy projektu zaproponowali bardzo szeroką gamę rekomendacji w zakresie polityki na rzecz rodziny - poczynając od zwiększania ulg podatkowych, subsydiowania składek na ubezpieczenia społeczne rodziców opiekujących się dziećmi na urlopach wychowawczych, przez prorodzinne zmiany w ochronie zdrowia, aż po wydłużenie urlopu macierzyńskiego i większe nakłady finansowe na przedszkola i żłobki [Sobociński 2016, s. 42]. W projekcie wiele miejsca poświęcono sytuacji kobiet, zwłaszcza młodych, które nie tylko postrzegano przez pryzmat ról macierzyńskich, ale również dostrzeżono w nich osoby aktywne zawodowo. Co interesujące, w części dokumentu obejmującej diagnozę sytuacji polskich rodzin stwierdzono m.in., że: prawdopodobieństwo podjęcia decyzji o urodzeniu dziecka rośnie, gdy kobieta ma pracę, doświadczenie zawodowe i poczucie stabilizacji na rynku pracy. Stwierdzenie takie wskazywałoby na konieczność odejścia od dominującego w Polsce modelu familialistycznego, opartego na wspieranej przez państwo opiece nad dziećmi przez matkę, która na dłuższe okresy opuszcza rynek pracy. Jednakże autorzy projektu - świadomie lub nie - w części rekomendacji, zwłaszcza dotyczących wydłużenia i polepszenia jakości urlopów macierzyńskiego i wychowawczego, de facto zaproponowali rozwiązania prowadzące do umocnienia się przyczyn niskiej dzietności, które w tym samym tekście zdiagnozowali. Plany pokrzyżowała zmiana układu sił w parlamencie, tym razem w wyniku rozpadu koalicji rządzącej, samorozwiązania Sejmu i wcześniejszych wyborów, w których zwyciężyła Platforma Obywatelska [Sobociński 2016, s. 42-43]. 
Realizacja programu zakładała osiągnięcie następujących efektów [Program polityki rodzinnej 2007]:

- wzrost liczby urodzeń (odwrócenie niekorzystnego trendu demograficznego),

- poprawę jakości życia i kondycji polskich rodzin,

- wsparcie dla rodziców w godzeniu pracy i życia rodzinnego, w tym równe traktowanie płci,

- wsparcie finansowe dla rodzin,

- rozwój społeczeństwa przyjaznego dzieciom i rodzinom.

\section{Program polityki rodzinnej „Dobry klimat dla rodziny” z 2013 r.}

W latach 2010-2015 prezydent Komorowski określił politykę rodzinną jako jeden z priorytetów swojej prezydentury. Zaproponowany przez Kancelarię Prezydenta Program polityki rodzinnej „Dobry klimat dla rodziny” [Program polityki rodzinnej 2013] w 2013r. położył fundamenty pod prezydencki projekt tzw. ustawy rodzinnej z 2015 r., a więc reformy Kodeksu pracy, które miały na celu ułatwienie godzenia pracy zawodowej z opieką nad dziećmi. Zmiany te dotyczą przede wszystkim elastyczności godzin pracy dla rodziców oraz większej elastyczności urlopu rodzicielskiego i ojcowskiego. Nie wprowadzają jednak nowych instrumentów polityki rodzinnej ani nie rozszerzają indywidualnych uprawnień ojców, co było jednym z głównych postulatów wielu ekspertów w procesie konsultacji projektu [Sobociński 2016, s. 44].

Tabela 3. Struktura dokumentów polityki rodzinnej w latach 1997-2013

\begin{tabular}{|c|c|c|c|c|}
\hline $\begin{array}{l}\text { Nazwa } \\
\text { programu }\end{array}$ & $\begin{array}{l}\text { Liczba } \\
\text { stron }\end{array}$ & $\begin{array}{l}\text { Liczba działań } \\
\text { kierunkowych }\end{array}$ & Części programu & Analiza nakładów \\
\hline 1 & 2 & 3 & 4 & 5 \\
\hline $\begin{array}{l}\text { Projekt } \\
\text { programu } \\
\text { polityki } \\
\text { rodzinnej } \\
\text { z } 10 \text { czerwca } \\
1997 \mathrm{r} \text {. }\end{array}$ & 4 & $\begin{array}{l}\text { działań } \\
\text { kierunkowych }\end{array}$ & $\begin{array}{l}8 \text { części programu } \\
\text { 1. Warunki realizacji ekonomicznej funkcji } \\
\text { rodziny. } \\
\text { 2. Warunki mieszkaniowe rodzin. } \\
\text { 3. Warunki realizacji opieki nad dzieckiem. } \\
\text { 4. Warunki realizacji wychowawczej } \\
\text { i kulturalnej funkcji rodziny. } \\
\text { 5. Ochrona prawna rodziny. } \\
\text { 6. Ochrona zdrowia rodziny. } \\
\text { 7. Pomoc rodzinom z osobą niepełnosprawną. } \\
\text { 8. Pomoc rodzinie zagrożonej dysfunkcją. }\end{array}$ & brak \\
\hline $\begin{array}{l}\text { Projekt } \\
\text { programu } \\
\text { polityki } \\
\text { prorodzinnej } \\
\text { z } 3 \text { listopada } \\
1999 \mathrm{r} \text {. }\end{array}$ & 14 & $\begin{array}{l}8 \text { działań } \\
\text { kierunkowych }\end{array}$ & $\begin{array}{l}\text { 11 części programu } \\
\text { 1. Zmiana sytuacji demograficznej i struktury } \\
\text { rodzin. } \\
\text { 2. Poprawa sytuacji finansowej rodzin. } \\
\text { 3. Poprawa warunków mieszkaniowych. } \\
\text { 4. Wychowanie młodego pokolenia. } \\
\text { 5. Poprawa stanu zdrowia rodziny. }\end{array}$ & \\
\hline
\end{tabular}


Tabela 3, cd.

\begin{tabular}{|c|c|c|c|c|}
\hline 1 & 2 & 3 & 4 & 5 \\
\hline & & & $\begin{array}{l}\text { 6. Pomoc rodzinom z osobami } \\
\text { niepełnosprawnymi. } \\
\text { 7. Opieka nad dzieckiem. } \\
\text { 8. Pomoc rodzinom zagrożonym } \\
\text { dysfunkcjami. } \\
\text { 9. Polskie rodziny poza granicami kraju. } \\
\text { 10. Kultura i media a rodzina. } \\
\text { 11. Ochrona prawna rodzin. }\end{array}$ & $\begin{array}{l}\text { brak innych źródeł } \\
\text { finansowania niż } \\
\text { budżet państwa }\end{array}$ \\
\hline $\begin{array}{l}\text { Projekt polityki } \\
\text { rodzinnej } \\
\text { z } 8 \text { marca } \\
2007 \text { r. }\end{array}$ & 22 & $\begin{array}{l}3 \text { działania } \\
\text { kierunkowe }\end{array}$ & $\begin{array}{l}9 \text { części programu } \\
\text { 1. Przeciwdziałanie dyskryminacji rodzin } \\
\text { w zakresie systemu podatkowego } \\
\text { i emerytalno-rentowego. } \\
\text { 2. Wysokie koszty opieki zdrowotnej nad } \\
\text { kobietą i dzieckiem. } \\
\text { 3. Urlopy macierzyńskie. } \\
\text { 4. Pomoc dla rodzin w trudnej sytuacji } \\
\text { finansowej. } \\
\text { 5. Skuteczna pomoc rodzinie niewydolnej } \\
\text { wychowawczo, rodziny w kryzysie. } \\
\text { 6. Godzenie roli rodzica z innymi rolami } \\
\text { społecznymi. } \\
\text { 7. Jakość i dostępność infrastruktury } \\
\text { wspierającej proces wychowania dzieci. } \\
\text { 8. Godzenie pracy i macierzyństwa. } \\
\text { 9. Tworzenie pozytywnego klimatu wokół } \\
\text { rodzicielstwa. }\end{array}$ & $\begin{array}{l}\text { zawiera } \\
\text { finansowanie } \\
\text { - wymaga } \\
\text { uszczegółowienia }\end{array}$ \\
\hline $\begin{array}{l}\text { Projekt } \\
\text { programu } \\
\text { polityki } \\
\text { rodzinnej } \\
\text { „Dobry klimat } \\
\text { dla rodziny” } \\
\text { z maja } 2013 \text { r. }\end{array}$ & 30 & $\begin{array}{l}7 \text { kluczowych } \\
\text { zasad i } 44 \\
\text { szczegółowe } \\
\text { rekomendacje }\end{array}$ & $\begin{array}{l}5 \text { części programu } \\
\text { 1. Samodzielność finansowa rodzin. } \\
\text { 2. Samodzielne mieszkanie. } \\
\text { 3. Godzenie pracy z obowiązkami domowymi: } \\
\text { a) czas i organizacja pracy przyjazne rodzinie, } \\
\text { b) elastyczny i przejrzysty system urlopów } \\
\text { związanych z opieką nad dzieckiem, } \\
\text { c) dostępne, wysokiej jakości usługi opieki } \\
\text { i edukacji dzieci do } 12 \text { lat, } \\
\text { d) równość w pracy. } \\
\text { 4. Dobre rodzicielstwo. } \\
\text { 5. Wspólne tworzenie klimatu dla rodziny. }\end{array}$ & $\begin{array}{l}\text { zawiera } \\
\text { finansowanie } \\
\text { - wymaga } \\
\text { uszczegółowienia }\end{array}$ \\
\hline
\end{tabular}

Źródło: opracowanie własne na podstawie zebranych materiałów.

Realizacja programu zakładała osiągnięcie następujących efektów:

- odwrócenie niekorzystnego trendu demograficznego,

- wypracowanie trwałych i konsekwentnych rozwiązań, które stworzyłyby stabilne warunki do decyzji o rodzicielstwie,

- nawiązanie szerokiej współpracy i akceptacji społecznej rządu i parlamentu, w tym odpowiedniej legislacji, samorządów i społeczności lokalnych, organiza- 
cji pracodawców i związków zawodowych, organizacji pozarządowych, kościołów oraz związków wyznaniowych i mediów,

- $\quad$ elastyczność pozwalającą rodzicom wybierać różne strategie łączenia wychowywania najmłodszych dzieci z pracą,

- poprawę sytuacji finansowej rodzin,

- korzystną sytuację mieszkaniową dla młodych małżeństw,

- rozwój społeczeństwa przyjaznego dzieciom i rodzinom.

\section{Zakończenie}

\section{Ogólne podsumowanie}

Jednym z najczęściej powtarzanych w debacie publicznej i naukowej zarzutów wobec polityki państwa na rzecz rodziny już od 1997 r. jest brak kompleksowego systemu polityki rodzinnej i doraźność wielu stosowanych działań i instrumentów. W analizowanym okresie 1997-2013 powstały cztery strategiczne programy rządowe w całości poświęcone polityce rodzinnej (w latach 1997, 1999, 2007 i 2013). Wpływ tych dokumentów na realny kurs polityki na rzecz rodziny należy uznać za wątpliwy. Realizacja zawartych w programach postulatów ograniczona była z powodu ogólnej niestabilności systemu partyjnego w Polsce oraz częstych zmian rządów.

Od dnia przystąpienia Polski do Unii Europejskiej, tj. od 1 maja 2004 r. upłynie niedługo 12 lat. W tym czasie zaczęły się zmiany w obszarze polityki rodzinnej i prorodzinnej. Od roku 2006 możemy mówić o pewnej konsolidacji wysiłków państwa na rzecz rodziny, jednak cały czas pozostaje problem dotyczący traktowania obszaru polityki rodzinnej jako domkniętego systemu w zakresie zarówno explicite, jak i implicite. Podsumowując opisane zmiany, należy dostrzec następujące sposoby rozszerzenia interwencji państwa w zakresie polityki rodzinnej (po 2008 r.): zwiększenie finansowego wspierania rodzin, a przede wszystkim rodzin z dziećmi, w tym wielodzietnych; wydłużenie i uelastycznienie urlopów z tytułu opieki nad dzieckiem (dla matek, a także ojców) oraz zdywersyfikowanie i wspieranie rozwoju instytucjonalnych i indywidualnych form opieki nad małym dzieckiem (do lat trzech oraz w zakresie edukacji przedszkolnej i wczesnoszkolnej). Jak zauważa J. Szczepaniak-Sienniak jest to godne podkreślenia, tym bardziej że zmiany te nastąpiły w okresie ogólnoświatowego kryzysu ekonomicznego (z 2008 r.), a ten - jak uważa wielu badaczy - niesie ze sobą szczególne zagrożenia dla możliwości ingerencji państwa w sprawy społeczne [Szczepaniak-Sienniak 2015, s. 102, 112].

Z przedstawienia poszczególnych programów polityki rodzinnej oraz głównych kierunków polityki państwa na rzecz rodziny zawartych w czterech analizowanych dokumentach (co było celem niniejszego artykułu) wynikają następujące wnioski.

\section{Wnioski}

Od roku 1997 r. można mówić o pojawieniu się bardzo ważnej cechy charakterystycznej dla polityki rodzinnej w Polsce, a więc silnego pronatalizmu, który pod- 
porządkował sobie inne cele działań państwa na rzecz rodziny. Niezwykle ważny okazał się obrany kierunek pomocy i charakter działań. W programie z 1997 r. grupą szczególną były wszystkie rodziny posiadające i utrzymujące dzieci z dysfunkcjami i młodzież - działania miały charakter działań uzupełniających. Z przeprowadzonej analizy programu z 1997 r. wynikają następujące główne konkluzje:

Zalety:

1. Był to pierwszy program dotyczący polityki na rzecz rodzin.

2. Rodzina i jej członkowie traktowani jako kapitał społeczny, w który trzeba inwestować, szczególnie gdy dotyczy to młodego pokolenia.

3. Upowszechnienie opieki przedszkolnej, przekształcanie placówek pielęgnacyjnych w opiekuńczo-wychowawcze, promowanie alternatywnych form opieki nad dziećmi, takich jak społeczne czy domowe żłobki, tworzenie oddziałów przedszkolnych przy szkołach.

4. Wspieranie rodziny w sprawowaniu przez nią funkcji wychowawczej, co zostało szeroko ujęte:

- $\quad$ po pierwsze, od najmłodszych lat dziecko powinno uczęszczać do żłobka, przedszkola,

- po drugie, dążono do zwiększenia uczestnictwa dzieci w kulturze ogólnonarodowej.

5. Zakładano również rozwój aktywności fizycznej i rekreacyjnej, poprzez kształtowanie nowego modelu form spędzania czasu wolnego.

\section{Wady:}

1. Zbyt ogólny charakter dokumentu.

2. Objęcie ochroną rodzin najuboższych.

3. Brak szczegółowo scharakteryzowanej grupy docelowej.

4. Brak analizy nakładów.

W latach 1999-2005 koalicja centroprawicy zdecydowanie mocniej podkreślała znaczenie tradycyjnych wartości rodzinnych i w deklaracjach programowych częściej odwoływała się explicite do „dobra rodziny” niż kolejne rządy. W programie polityki rodzinnej z 1999 r. zdiagnozowano problem starzejącego się społeczeństwa i spadającej dzietności, co skłoniło kolejne rządy do opracowania bardziej przekrojowych programów polityki rodzinnej, w których na czołowych pozycjach znajdowały się działania na rzecz zwiększenia liczby urodzeń. Grupą docelową w programie z 1999 r., na której miała skupiać się pomoc, były głównie rodziny z dysfunkcjami w trudnej sytuacji, a działania na ich rzecz miały mieć charakter działań interwencyjnych i uzupełniających. Z przeprowadzonej analizy programu z 1999 r. wynikają następujące główne konkluzje:

\section{Zalety:}

1. Dokument przedstawiał analizę problemów wraz z rozwiązaniami i finansowaniem. 
2. Zmiana dominującej zasady opiekuńczości na zasadę pomocniczości dla rodziny i jej członków.

3. Po raz pierwszy zmieniony na bardziej prorodzinny system podatkowy, ze szczególnym uwzględnieniem rodzin wielodzietnych i niepełnych.

4. Zwiększenie liczby placówek oświatowo-wychowawczych i wdrażanie specjalnych programów aktywności kulturalnej.

5. Edukacja prozdrowotna rodziców i dzieci.

6. Działania eliminujące zjawisko dziedziczenia biedy, bezrobocie oraz szeroko pojęte patologie społeczne.

7. Dążenie do zrównoważenia uprawnień i przywilejów dla kobiet i mężczyzn, zgodnie z zasadą odpowiedzialności obojga rodziców za dzieci.

8. Współpraca z samorządami lokalnymi oraz organizacjami pozarządowymi.

\section{Wady:}

1. Selektywność przyznawanych zasiłków.

2. Brak innych źródeł finansowania niż budżet państwa (uzależniony od sytuacji gospodarczej).

Od 2007 r. wzrastała świadomość twórców programu polityki rodzinnej na temat pozytywnego wpływu powrotu kobiet na rynek pracy na decyzje o posiadaniu dzieci, stąd nacisk na wydłużenie urlopu macierzyńskiego oraz godzenia życia zawodowego z rodzinnym. W programie z 2007 r. proponuje się wprowadzenie nowych instrumentów (urlop rodzicielski i ojcowski, ulga na dziecko). Grupą, do której kierowane ma być największe wsparcie, są rodziny w trudnej sytuacji z naciskiem na rodziny wielodzietne i wiejskie, a podjęte działania mają mieć charakter interwencyjny i uzupełniający. Z przeprowadzonej analizy programu z 2007 r. wynikają następujące główne wnioski:

\section{Zalety:}

1. Dokument przedstawiający diagnozę, problemy wraz z rozwiązaniami i finansowaniem.

2. Po raz pierwszy wprowadzenie przeciwdziałania dyskryminacji rodzin w zakresie systemu podatkowego i emerytalno-rentowego.

3. Wprowadzenie zachęt dla pracodawców, aby przedłużali zatrudnienie osobom wracającym po przerwie spowodowanej urodzeniem lub wychowywaniem dziecka.

4. Zmiana wizerunku macierzyństwa, zwłaszcza w kontekście akceptacji dla istniejących i utrwalających się procesów łączenia życia rodzinnego z samorealizacją kobiet.

5. Tworzenie pozytywnego klimatu dla rodzicielstwa (np. konkurs na pracodawcę przyjaznego dzieciom, miejsca parkingowe dla osób z małymi dziećmi, przewijaki i miejsca do karmienia w miejscach publicznych).

6. Ułatwienie godzenia pracy z macierzyństwem przez uelastycznianie organizacji pracy dla kobiet w ciąży i z małym dzieckiem (telepraca, job sparing, elastyczny czas pracy, praca zadaniowa, ruchomy czas pracy). 


\section{Wady:}

1. W projekcie brakuje kompleksowych rozwiązań dla rodzin z dzieckiem niepełnosprawnym oraz rodzin wielodzietnych, szczególnie w Polsce zagrożonych ubóstwem. Pominięto rodziny wiejskie, które mają ograniczony dostęp do usług zdrowotnych, opiekuńczych, edukacyjnych; Brak innych źródeł finansowania niż budżet państwa (uzależniony od sytuacji gospodarczej).

2. Pomimo że w projekcie zdiagnozowano problem źle zorganizowanej i mało efektywnej pracy socjalnej z rodziną w sytuacjach kryzysowych, to jednak nie znalazły się tam propozycje, które miałyby charakter prewencyjny i zapobiegałyby kierowaniu dzieci do opieki zastępczej.

3. Projekt traktowany raczej jako „dobry start”, a proponowane rozwiązania jako zmierzające w dobrym kierunku, ale wymagające dopracowania.

Od 2013 r. problem spadającej dzietności został szerzej dostrzeżony w debatach politycznych i publicznych. To również okres konsolidacji polityki rodzinnej w Polsce, czas wprowadzania nowych instrumentów i rozszerzania istniejących oraz reform. Program przede wszystkim przewidywał i wprowadził z sukcesem Ogólnopolską Kartę Dużych Rodzin, ustanawiającą powszechne zniżki w opłatach za usługi publiczne dla rodzinwielodzietnych. Pomoc o charakterze działań interwencyjnych, prewencyjnych i aktywizujących została skierowana do wszystkich typów rodzin. Z przeprowadzonej analizy programu z 2013 r. wynikają następujące główne konkluzje:

\section{Zalety:}

1. Dokument przedstawiający diagnozę, problemy, analizę wraz z rozwiązaniami i finansowaniem.

2. Dobrze uzasadnione propozycje celów, w większości bazujące na wnikliwych analizach danych empirycznych.

3. Zwiększenie liczby miejsc opieki dla dzieci do lat 3 oraz wprowadzenie bonów opiekuńczych.

4. Wprowadzenie kwoty wolnej od podatku uzależnionej od liczby dzieci $\mathrm{w}$ rodzinie.

5. Wydłużenie urlopów macierzyńskich i rodzicielskich proporcjonalnie do wymiaru czasu pracy w sytuacji łączenia urlopów z pracą na część etatu.

6. Program tanich mieszkań na wynajem.

7. Ogólnopolska Karta Dużej Rodziny.

8. Dobry klimat dla rodziny i rodzicielstwa.

Wady:

1. Brak uszczegółowionej analizy finansowej wprowadzanych przedsięwzięć.

\section{Rekomendacje}

Polityka rodzinna oraz jej instrumenty zarówno w okresie transformacji, jak i po 2004 r. traktowane były głównie jako forma interwencji i prewencji. W okresie tym 
wsparcie dla rodzin polegało na wykorzystywaniu przede wszystkim świadczeń finansowych opartych na regulacjach prawnych. Pomoc dla rodzin przewidziano na zasadzie pasywno-doraźnych form pracy tych instytucji. Stąd też dyskusje wielu politologów i polityków społecznych dotyczyły samego sformułowania pojęcia polityki rodzinnej, przechylając szalę definicji w stronę doraźnej polityki na rzecz rodzin.

W zakresie polityki rodzinnej nadal brakuje spójnego (ujednoliconego) programu bądź strategii, która łączyłaby ze sobą szereg instrumentów bezpośrednich i pośrednich polityki rodzinnej. Nadal istniejącą barierą w rozwoju funkcji prokreacyjnej rodziny jest świadomy wybór rodziców - posiadania małej liczby dzieci.

Z politycznego, społecznego i ekonomicznego punktu widzenia państwo powinno być zainteresowane polityką pronatalistyczną w kraju. Dziecko należy traktować w kategorii dobra publicznego. Przy takim podejściu polityka społeczna na rzecz rodzin nie jest pojmowana jako koszt, ale jako inwestycja, która zwraca się w następnym pokoleniu lub pokoleniach. Dlatego też polityka rodzinna powinna skupiać się nie tylko na tradycyjnych, formalnych związkach małżeńskich, ale również „otworzyć się" na nowe, alternatywne formy życia rodzinnego (kohabitacja, LAT - Living Apart Together itp.), w których obecnie rodzi się w Polsce ok. 1/3 dzieci.

Zadawane przez wielu politologów i polityków społecznych pytanie, jaki model rodziny powinien być wspierany przez politykę rodzinną, znalazło częściową odpowiedź w rozwiązaniach prorodzinnych wprowadzanych w latach 1997-2013. Na przestrzeni kilkunastu ostatnich lat (1997-2013) zmianie uległa formuła roli polityki rodzinnej w tworzeniu kapitału ludzkiego i społecznego. Zaspokojenie potrzeb rodziny, a przede wszystkim proces wychowania to udział rodziny w budowaniu tych kapitałów. Dlatego też obecnie prowadzona polityka rodzinna zmierza do wsparcia rodziny w realizacji jej społecznych funkcji. Kontynuowanie kreowania polityki rodzinnej w takim kierunku pozwoli w perspektywie długoterminowej osiągnąć wysoką jakość przyszłego kapitału ludzkiego, społecznego i kreatywnego oraz wysoką świadomość społeczną i gospodarczą przyszłych pokoleń. Aby kompleksowo sprostać obecnym wyzwaniom demograficznym oraz realizować spójną racjonalną i efektywną politykę rodzinną, powinny zostać uwzględnione poniższe aspekty:

- jeden spójny zatwierdzony program polityki rodzinnej państwa,

- wykorzystanie dobrych praktyk z poprzednich dokumentów oraz prawie 20 letniego doświadczenia $\mathrm{w}$ realizacji polityki na rzecz rodzin,

- uwzględnienie innych źródeł finansowania niż tylko budżet państwa,

- faktyczne zaangażowanie innych grup (związki zawodowe, NGOs itd.),

- większe wykorzystanie doświadczeń innych krajów w zakresie realizacji polityki rodzinnej.

Polityka rodzinna prowadzona przez państwo nie może być traktowana jako pole do działań incydentalnych, o charakterze „deski ratunkowej”, lecz jako długookresowe, systemowe wsparcie ukierunkowane na wszystkie rodziny wychowujące potomstwo. Rola państwa w kreowaniu polityki rodzinnej polega na kształtowaniu warunków sprzyjających realizacji podstawowego zadania rodziny - rozwoju biolo- 
gicznego poprzez realizację funkcji prokreacyjnej, ale również możliwość realizacji wybranego przez rodziny model dzietności, a w szerszym znaczeniu - modelu pożądanego społecznie, a więc zapewniającego rozwój biologiczny społeczeństwa.

\section{Literatura}

Balcerzak-Paradowska B., 2004a, Rodzina i polityka rodzinna na przełomie wieków, Wydawnictwo IPiSS, Warszawa.

Balcerzak-Paradowska B., 2004b, Rola państwa w ksztaltowaniu polityki rodzinnej w Polsce w okresie transformacji, [w:] Graniewska D. (red.), Sytuacja rodzin i polityka rodzinna w Polsce. Uwarunkowania demograficzne i społeczne, Wydawnictwo IPISS, Warszawa.

Chodubski A.J., 2004, Wstęp do badań politologicznych, Wydawnictwo Uniwersytetu Gdańskiego, Gdańsk.

Durasiewicz A., 2016, Analisys of the axiological-social, instytutional and legal sphere of the family policy in selected EU countries, [w:] Lubkina V., Usca S., Zvaigzne A. (red.), Society. Integration. Education. Proceedings of the International Scientific Conference, Scientific Council of Rezekne Augstskola, Rezekne.

Program polityki prorodzinnej, 1999, Przegląd Rządowy, nr 11-12, s. 130-143.

Program polityki rodzinnej, 1997, Przegląd Rządowy, nr 8-9, s. 227-230.

Projekt polityki rodzinnej „Dobry klimat dla rodziny” 2013, s. 1-6, http://www.przymierze.org.pl/index.php?option=com_content\&task=view\&id=141\&Itemid=34 (8.06.2016).

Projekt polityki rodzinnej 2007 pod kierownictwem Joanny Kluzik-Rostkowskiej, s. 3-4, http://www. prezydent.pl/archiwum-bronislawa-komorowskiego/dla-rodziny/program-polityki-rodzinnej-prezydenta-rp/ (8.06.2016).

Sobociński M., 2016, Kierunki polityki państwa wobec rodziny w latach 1989-2015, Studia BAS, nr 1(45), Warszawa.

Szczepaniak-Sienniak J., 2015, Polityka rodzinna państwa we współczesnej Polsce, Społeczeństwo i Ekonomia, nr 2 (4), Wydawnictwo Uniwersytetu Ekonomicznego we Wrocławiu, Wrocław.

Znaniecki F., 1984, Społeczne role uczonych, PWN, Warszawa. 